\title{
SINGLE-SPECIES AND MULTIPLE-SPECIES CONNECTIVITY MODELS FOR LARGE MAMMALS ON THE NAVAJO NATION
}

\author{
Erica Fleishman ${ }^{1,3}$, Jesse Anderson ${ }^{2}$, and Brett G. Dickson ${ }^{2}$
}

\begin{abstract}
Estimation of connectivity for multiple species could increase the efficiency of resource management and elucidate trade-offs among maintenance of connectivity for different taxa. We identified potential areas of high connectivity for 5 species of mammals on the Navajo Nation and adjacent lands in Utah, Arizona, and New Mexico, USA: mountain lion (Puma concolor), mule deer (Odocoileus hemionus), desert bighorn sheep (Ovis canadensis nelsoni), American black bear (Ursus americanus), and pronghorn (Antilocapra americana). These species were identified by the Navajo Nation as relevant to the benefit of their present and future generations. We used telemetry data to calculate utilization distributions, derive model permeability (the probability that a given location facilitates animal movement), and assess connectivity (the realization of permeability across a landscape) for desert bighorn sheep, black bear, and pronghorn. We based models of connectivity for mountain lion and mule deer on expert-identified environmental variables and corresponding permeability values. We used Circuitscape software to model omnidirectional connectivity for each species, and then used maps of connectivity to identify potential dispersal areas. Different environmental features were associated with connectivity for each species. The rank correlation between the geographic distribution of connectivity for pairs of species ranged from -0.45 to 0.95 . All but one of the estimated pairwise overlaps in potential dispersal areas were greater than would be expected if dispersal areas for each species were independent. The percentage of overlap generally decreased as a greater number of species was considered, but was greater than expected in 6 of 10 cases for 3 species and all cases for 4 or 5 species. Potential dispersal areas for all 5 species occurred within $83 \mathrm{~km}^{2}$ of the approximately $72,000-\mathrm{km}^{2}$ analysis area. Our work illustrates use of a flexible method for estimating connectivity and potential dispersal areas, particularly where data on the distribution and movements of populations are limited.
\end{abstract}

RESUMEN.-La estimación de la conectividad de múltiples especies podría aumentar la eficiencia del manejo de los recursos y esclarecer las disyuntivas entre el mantenimiento de la conectividad de los diferentes taxa. Identificamos potenciales áreas de alta conectividad para cinco especies de mamíferos: puma (Puma concolor), ciervo mula (Odocoileus hemionus), borrego cimarrón (Ovis canadensis nelsoni), oso negro (Ursus americanus) y antílope americano (Antilocapra americana), en la Nación Navajo y en las tierras adyacentes a Utah, Arizona y Nuevo México, en los Estados Unidos de América. Estas especies fueron identificadas como relevantes, por la Nación Navajo, para el beneficio de sus generaciones presentes y futuras. Utilizamos telemetría para calcular la utilización de la distribución, la permeabilidad del modelo (la probabilidad de que un sitio determinado facilite el desplazamiento), y para evaluar la conectividad (la realización de la permeabilidad) del borrego cimarrón del desierto, del oso negro y del antílope americano. Basamos los modelos de conectividad de los pumas y de los venados en variables ambientales identificadas por expertos y en los valores de permeabilidad correspondientes. Utilizamos el software Circuitscape para modelar la conectividad omnidireccional de cada especie, y luego utilizamos mapas de conectividad para identificar posibles áreas de dispersión. Diferentes características ambientales se asociaron a la conectividad en cada especie. El rango de correlación entre la distribución geográfica de conectividad por pares de especies varió de -0.45 a 0.95 . Todos excepto uno de los pares estimados superpuestos en posibles áreas de dispersión fueron mayores de lo previsto, si tales áreas de dispersión fuesen independientes en cada especie. El porcentaje de superposición disminuyó al considerarse un mayor número de especies, pero fue mayor de lo esperado en seis de diez casos en tres especies y en todos los casos en cuatro o cinco especies. Las áreas potenciales de dispersión para las cinco especies ocurrieron dentro de $83 \mathrm{~km}^{2}$ de los $\sim 72,000 \mathrm{~km}^{2}$ del área de análisis. Nuestro trabajo ilustra el uso de un método flexible para estimar la conectividad y las posibles áreas de dispersión, particularmente donde la información sobre la distribución y las dispersión de las poblaciones es limitada.

Fragmentation of habitat by land use and climate change is a primary challenge to conservation of wildlife, and species persistence may rely on maintenance or restoration of connectivity among populations (Krosby et al. 2010). Therefore, efforts to protect or restore areas through which wildlife may move are increasingly common (Kool et al. 2013). Consideration of the movements of multiple species may maximize realization of the desired effects of protection and minimize the costs of restoration (Beier et al. 2011). However,

\footnotetext{
1John Muir Institute of the Environment, The Barn, One Shields Avenue, University of California, Davis, CA 95616. E-mail: efleishman@ucdavis.edu ${ }^{2}$ Conservation Science Partners, 11050 Pioneer Trail, Suite 202, Truckee, CA 96161.

${ }^{3}$ Present address: Department of Fish, Wildlife and Conservation Biology, Colorado State University, Fort Collins, CO 80523.
} 
analyses of connectivity for multiple species, and actions that explicitly aim to maintain connectivity for multiple species, are relatively rare (Cushman and Landguth 2012, Magris et al. 2016, Santini et al. 2016).

Assessments of connectivity for multiple species primarily are limited by insufficient data or the inapplicability of existing connectivity models to the species of interest (Correa Ayram et al. 2016). As a result, many such assessments have extended existing speciesspecific models to additional species. For example, some researchers evaluated whether conservation of movement corridors for one species may facilitate dispersal of other species (e.g., Cushman and Landguth 2012, Breckheimer et al. 2014). In one case, for instance, conservation of dispersal habitat for a particular species of woodpecker, butterfly, or frog also would conserve dispersal habitat for the other 2 species (Breckheimer et al. 2014). Researchers also have applied models that are presumed to be species-neutral and represent the extent to which human activity has modified a landscape (Theobald et al. 2012), or models that partition a region into areas with generally similar environmental attributes (Brost and Beier 2012). If the suite of species is large or demonstrably affected by land use, then a model that focuses on the degree of human modification may be appropriate (Theobald et al. 2012). For example, the overlap between composite corridors of 10 species and movement corridors estimated on the basis of degree of human modification was equivalent to the overlap between those composite corridors and movement corridors estimated from data on a small number of focal species (Krosby et al. 2015).

Conversely, evidence of minimal overlap of areas through which 2 or more species move may indicate that multiple models are necessary. For example, separate carnivore- and herbivore-based models for 5 threatened mammal species in Borneo increased the projected cost of movement for each species less than a single model for all species (Brodie et al. 2015).

Data availability also affects which methods can be used to estimate permeability (the probability that a given location facilitates animal movement) and connectivity (the realization of permeability across a landscape) for single species (Zeller et al. 2012). The parameterization of a permeability layer usually is informed by either expert knowledge or empirical data, such as presence-absence data or movement data obtained with radio telemetry (Spear et al. 2010), or by methods including expert elicitation, resource selection functions, or occupancy models (Zeller et al. 2012). The permeability layer then can be used to assess connectivity via least-cost path analysis (e.g., Singleton et al. 2002), graph theory (Bunn et al. 2000), flow paths (Carroll et al. 2012), circuit theory (McRae et al. 2008), or other methods. The outputs of the above types of spatially explicit connectivity models-typically rasters or grids-can range from quantitative estimates of movement likelihood or movement cost to simple indices of the quality of habitat for movement.

Methods based on electrical circuit theory, which map the full gradient of potential connectivity, can inform actions to facilitate gene flow and colonization (Loss et al. 2011) or to minimize the spread of nonnative invasive species (Glen et al. 2013) or undesirable disturbances, such as some wildland fires (Gray and Dickson 2015). These methods can be applied efficiently to diverse types of data, including coarse-resolution range maps for a given species, simple maps of habitat and nonhabitat within a species' range, or complex spatial data that represent gradients of habitat quality and impediments to movement (McRae et al. 2008).

The Navajo Nation is the largest sovereign, indigenous nation embedded within the United States. In the late 2000s, the Navajo Nation Department of Fish and Wildlife executed a needs analysis and assessment of critical issues to inform a 10 -year strategic plan that includes adaptive management. Analyses of connectivity were identified as potential sources of information for building adaptive capacity into the administration and implementation of the Navajo Nation's wildlife management agenda. The analyses were suggested as a means to project potential effects of climate change and to inform decisions about resource extraction and energy development. The department identified 5 species of large animals as relevant to the spiritual, cultural, and material benefit of present and future generations of the Navajo Nation: mountain lion (Puma concolor), mule deer (Odocoileus hemionus), desert bighorn sheep (Ovis canadensis nelsoni), American black bear (Ursus 


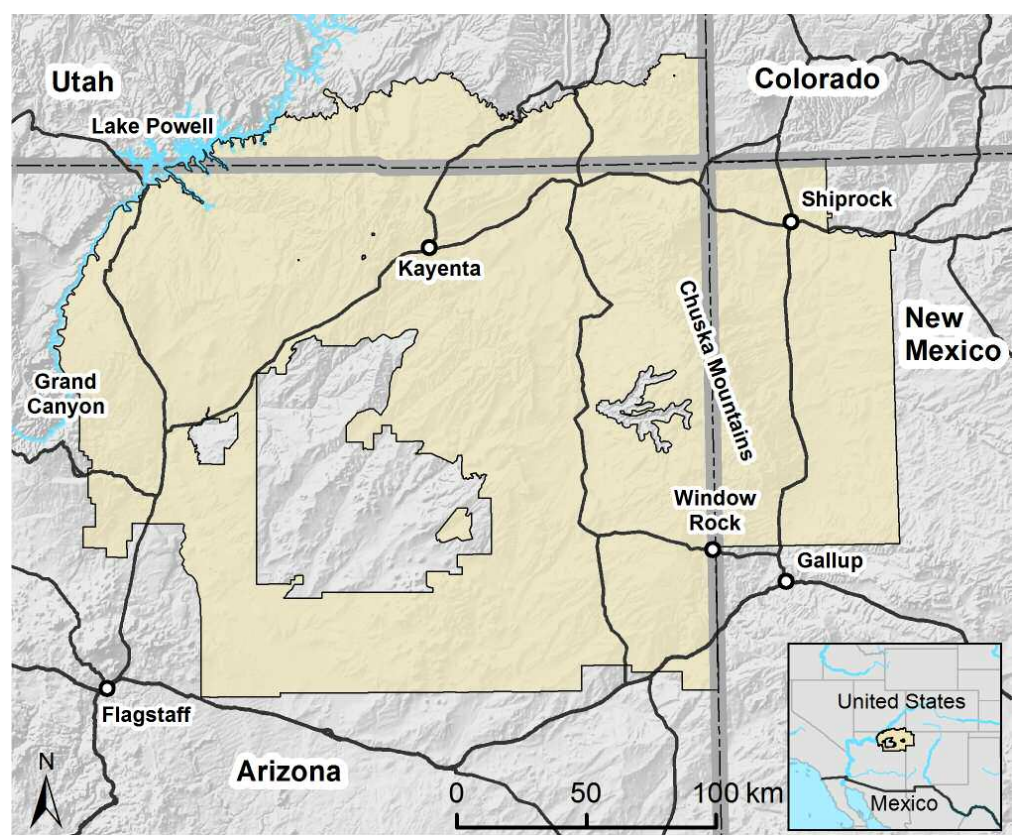

Fig. 1. The analysis area, including the Navajo Nation (in tan) and a 10-km buffer beyond its boundaries. The approximate bounding box of the analysis area (Universal Transverse Mercator [UTM] zone 12N, North American Datum [NAD] 1983) was north 4148000 , south 3880000 , east 758000 , west 411000 . Inset: location of the analysis area embedded within the western United States.

americanus), and pronghorn (Antilocapra americana). Two of these species, desert bighorn sheep and pronghorn, are listed by the Navajo Nation as group 3 endangered species, which are species or subspecies with prospects of survival or recruitment that are likely in jeopardy in the foreseeable future (Mikesic and Roth 2008).

We worked with the department to estimate connectivity and identify common potential dispersal areas for these 5 species on the Navajo Nation. Our shared goal was to inform land-use planning by identifying areas through which the probability of movement by one or more species was relatively high. Because each species was identified as a high priority, we did not attempt to apply the results from an analysis of connectivity for one species to other species. Given the low relative intensity of human activity across the analysis area, the application of species-neutral models likely would be uninformative. Instead, we used high-resolution telemetry data or expert knowledge to model permeability and estimate connectivity for each species, then assessed correlation of connectivity and over- lap of potential dispersal areas among multiple species.

\section{Methods}

We delineated our full analysis area as the Navajo Nation and a 10-km buffer around its perimeter (about $72,000 \mathrm{~km}^{2}$ ). We added the buffer to mitigate any edge-related artifacts during analysis. The approximate bounding box of the analysis area (Universal Transverse Mercator [UTM] zone 12N, North American Datum [NAD] 1983) was north 4148000 , south 3880000 , east 758000 , west 411000 (Fig. 1). The analysis area had a mean population density of 2.44 persons $/ \mathrm{km}^{2}$ in 2010 (census .gov) and is primarily semiarid, with a mean annual precipitation of approximately $23 \mathrm{~cm}$. The primary land-cover types are shrubland and woodland dominated by pinyon (Pinus edulis) and juniper (Juniperus osteosperma, J. monosperma).

We parameterized models of permeability for each species on the basis of the best information available. We sought data with high spatial and temporal resolution on the distribution and occurrence of each species across 
the analysis area, such as telemetry (very high frequency $[\mathrm{VHF}]$ or Global Positioning System [GPS]) data for many individuals over multiple seasons. Because such data from within the analysis area were limited and may not have provided consistent information on species occurrence, we utilized both GPS telemetry data from adjacent and nearby areas and expert knowledge compiled in previous works. Through an agreement with the Arizona Game and Fish Department, we obtained GPS telemetry data for desert bighorn sheep, black bears, and pronghorn that were monitored in areas adjacent to or within portions of the Navajo Nation. We conditioned models of permeability for mountain lions and mule deer on multiple environmental variables-abiotic and biotic attributes of habitat-that were identified by experts on the species. The systematic process of identifying those environmental variables occurred prior to the start of the work described here and is described in detail in Dickson et al. (2013).

Modeling Permeability for Desert Bighorn Sheep, Black Bears, and Pronghorn

The data we obtained from the Arizona Game and Fish Department included 137,195 telemetry locations for 40 desert bighorn sheep, recorded from 2008 through 2010, from a population near the Colorado River in western Arizona; 235,950 telemetry locations for 68 pronghorn, recorded from 2007 through 2010 , from a population near the southwest corner of the Navajo Nation; and 28,288 telemetry locations for 49 black bears, recorded from 2005 through 2011, from a population in eastern Arizona, western New Mexico, and areas within the Navajo Nation that otherwise would fall within these 2 states. Because black bears have annual periods of inactivity, we restricted our analysis to the 6700 locations recorded during the bears' most active period (hyperphagia, from 1 September until denning; Noyce and Garshelis 2011) in each year. The pronghorn data preserved any extensive annual movements, which are typical for this species during migration between their winter and summer ranges. Movements of bighorn sheep tend to be more restricted, but again the data captured any movements, such as those to access seasonal forage (Merkle et al. 2016).

We used the telemetry data to model each species' intensity of space use. We used a fixed kernel estimator to calculate a utilization distribution (UD; Worton 1989) at a 30-m resolution for each individual within each year. This method places a circular kernel over each cell in a regular lattice and counts the telemetry locations that fall within the kernel. The counts are multiplied by a weight that decreases as the distance from the center of the kernel increases (Silverman 1986). The bandwidth selector, $h$, defines the radius of the kernel and therefore the level of overall smoothing. We used cvh, or likelihood cross-validation, to select the bandwidth (Horne and Garton 2006; $\mathrm{R}$ code provided by J. Horne). The UDs provided a probabilistic estimate of the intensity of space use for each individual at a given location (see below and Willems and Hill 2009).

On the basis of a literature review (Mollohan 1987, DeCesare and Pletscher 2006, Atwood et al. 2011, Leu et al. 2011, Poor et al. 2012, Hoglander et al. 2015) and consultations with experts on the species, we selected environmental variables that we hypothesized would be strongly associated with intensity of space use for each species. Because our goal was to model habitat connectivity across the entire analysis area, we required data on these variables that encompassed the analysis area. To be included in the analysis, a given class of a categorical variable needed to overlap with the telemetry locations of individuals. In addition, we excluded a subset of variables that may be relevant to desert bighorn sheep, black bears, and pronghorn (such as density of roads or presence of humans) because values of those variables were uniformly low across the extent of the telemetry data. Within a geographic information system (GIS; ArcGIS v10.2, Esri, Redlands, CA), we compiled or derived raster data on the selected environmental variables from the Landscape Fire and Resource Management Planning Tools project (LANDFIRE, v1.2.0; landfire.gov). Base layers (or their derivatives) included in the models for all species included elevation, existing vegetation type, vegetation height, and percent cover of vegetation.

Variables that we included in models for desert bighorn sheep in shrubland cover types were shrub height, percent cover of shrubs, and the interaction between shrub height and percent cover of shrubs. Topographic variables included slope (in degrees), a vector ruggedness measure (Sappington et al. 2007), and 
topographic position (ridgelines, canyon bottoms, steep slopes, or gentle slopes; Dickson and Beier 2007). We derived the topographic variables from the elevation layer. None of the pairwise correlations between these variables exceeded 0.7 .

Models for black bears included vegetation type, percent cover of vegetation, and slope. We reclassified the vegetation type layer into 5 classes: forest, woodland, shrubland, grassland, and all other types inhabited by black bears. We also included interactions between percent cover of vegetation and forest, woodland, and shrubland.

Models for pronghorn included only vegetation-related variables: vegetation type reclassified into forest, woodland, shrubland, grassland, barren, and other inhabited types, as well as percent cover of forest and woodland.

We used linear mixed models to model space-use intensity (as estimated by the UDs) for each of the 3 species, conditioned on a set of environmental variables defined a priori. We centered the GIS layer representing each variable on zero and scaled to unit variance. We selected 500 random locations within the extent of each UD and recorded the value of that UD and each variable at each location (Willems and Hill 2009). We included a random intercept parameter, grouped by each individual within each year, to account for heterogeneity in annual space use among individuals. We modeled spatial autocorrelation among the locations for each individual by including an exponential spatial covariance structure, which we estimated on the basis of the same groups (Zuur et al. 2009). We used the Huber-White sandwich estimator (Williams 2000) to calculate standard errors in the presence of any remaining group-level heterogeneity.

For desert bighorn sheep, black bears, and pronghorn, we used multimodel inference to estimate model-averaged regression coefficients $(\widetilde{\beta})$ and unconditional standard errors for each fixed effect (Burnham and Anderson 2002). We derived models for each possible combination of the variables and used the difference in Akaike's information criterion (AIC) between each model and the model with the lowest AIC value ( $\triangle \mathrm{AIC})$ to calculate an AIC weight $\left(w_{i}\right)$ for each model (Anderson 2007). To estimate the relative strength of association between intensity of space use and each environmental variable, we summed the weights of each model in which a given variable was included $[w+(j)]$. We considered a value $\geq 0.50$ to indicate high strength of association between the response variable and the environmental variable (Barbieri and Berger 2004, Burnham 2015). We used the difference in AIC between the global model and the interceptonly model (including random effects and covariance structure) to evaluate how well our model structure fit the data. We considered a global model with an AIC value $>10.0$ units lower than the intercept-only model to indicate an excellent approximation of the data (Burnham and Anderson 2002). We implemented all models with SAS PROC MIXED (v9.3; sas.com) and used R (v3.0.3; r-project.org) to calculate model-averaged coefficients.

We used the model-averaged regression coefficients and the GIS to derive a raster layer representing permeability for each species. Similar to previous studies on these and other species, we assumed that areas with relatively high space-use intensity would contain relatively high-quality habitat, and that individuals would be more likely to move or disperse through these areas than through areas with lower space-use intensity (Chetkiewicz et al. 2006, Bleich et al. 2010, Atwood et al. 2011, Poor et al. 2012). We multiplied the model-averaged coefficient for each environmental variable across the corresponding GIS layer and then summed these results for all layers (i.e., a weighted linear combination). We rescaled the resulting permeability layer from 1 (low permeability) to 1000 (high permeability). We created a layer representing major barriers to movement, which included state and national highways with 2 or more lanes, large perennial lakes and reservoirs, and the Colorado River. Our hypothesis that these environmental attributes might impede movement reflected a literature review (Epps et al. 2005, Atwood et al. 2011, Poor et al. 2012) and examination of the telemetry data for each species. We derived the highway data from the 2011 National Transportation Atlas Database (bts.gov) and the hydrologic data from the National Hydrography Dataset (nhd.usgs.gov).

\section{Modeling Permeability for Mountain Lions and Mule Deer}

Telemetry data from within the Navajo Nation or in adjacent, similar areas were not available for mountain lions and mule deer. 
TABLE 1. Average of the expert-defined importance values and corresponding swing weights for the environmental variables used to estimate permeability for mountain lion and mule deer. Standard deviations are in parentheses.

\begin{tabular}{llcc}
\hline Species & Environmental variable & Importance value & Swing weight \\
\hline Mountain lion & Land-cover type & $1000.0(0.0)$ & 0.305 \\
& Terrain ruggedness & $733.3(208.2)$ & 0.223 \\
& Topographic position & $600.0(173.2)$ & 0.183 \\
& Road density & $233.3(57.7)$ & 0.071 \\
& Distance to water & $450.0(218.0)$ & 0.137 \\
Hule deer & Land-cover type & $133.3(57.7)$ & 0.041 \\
& Distance to perennial water & $800(141.4)$ & 0.193 \\
& Distance to highways & $450(70.7)$ & 0.108 \\
& Percent cover of shrubs & $350(70.7)$ & 0.084 \\
Topographic position & $550(353.6)$ & 0.133 \\
& Normalized Difference Vegetation Index & $700(0.0)$ & 0.169 \\
& Elevation & $450(212.1)$ & 0.108 \\
& Average annual precipitation & $200(0.0)$ & 0.048 \\
\hline
\end{tabular}

However, in prior work and separately for each species, 5 scientists and managers with regional expertise on mountain lions and 2 with regional expertise on mule deer were asked to identify a maximum of 4 environmental variables that they believed were associated strongly with permeability for either species in the southwestern United States. Aggregation of this information via a Delphilike process yielded 7 variables for mountain lions and 9 for mule deer. Environmental variables for mountain lions were existing dominant land-cover type, terrain ruggedness (the standard deviation of slope within an area), topographic position, road density, distance to perennial water, human population density, and presence of major barriers to movement (Table 1; Dickson et al. 2013). For mule deer, the environmental variables were existing dominant land-cover type, topographic position, distance to perennial water, distance to highways, percent cover of shrubs, the Normalized Difference Vegetation Index (NDVI), elevation, average annual precipitation, and presence of major barriers to movement (Table 1).

As described in detail in Dickson et al. (2013), each expert assessed and scored the extent to which each class of each environmental variable could facilitate movement of an individual. Scores ranged from 0 to 1000 , where 0 indicated low relative likelihood of movement through that class and 1000 indicated high likelihood. We used free, publicly available spatial data from multiple sources to derive all variables at the finest available resolution (typically $30 \mathrm{~m}$ ). We obtained data on existing vegetation types and shrub cover from LANDFIRE. We derived elevation and topographic position from the U.S. Geological Survey's National Elevation Dataset (30-m resolution; lta.cr.usgs.gov/NED). We used the U.S. Geological Survey's National Transportation Dataset (catalog.data.gov/dataset/usgsnational-transportation-dataset-ntd-download able-data-collectionde $7 \mathrm{~d} 2$ ) to calculate distance to highways with 2 or more lanes. We used the U.S. Geological Survey's National Hydrography Dataset (nhd.usgs.gov) to define perennial water features. We calculated maximum NDVI with Moderate Resolution Imaging Spectroradiometer (MODIS) data that covered 18 February 2000 through 16 March 2001. We estimated density of all roads within a $10-\mathrm{km}$ radius with the U.S. Census Bureau's TIGER/Line files. We derived human population density from block-level estimates made by the U.S. Census Bureau in census year 2000.

Next, each species expert defined an importance value, or swing weight, for each variable (rather than for each value or class of that variable; Malczewski 2000). Swing weights represent the relative change from the least to most permeable class of a given environmental variable, relative to a similar change in permeability among classes of another variable. The experts assessed which variable, at its maximum permeability, was most strongly associated with maintaining the species; we assigned a weight of 1000 to that variable. The experts then assessed the strength of association between the remaining variables and movement relative to the variable with the highest rank (Dickson et al. 2013). 
Within a GIS, we used a weighted linear combination of all variables to derive layers of permeability for mountain lions and mule deer on the basis of the expert-identified environmental variables, scores, and swing weights (Table 1, see also Supplementary Materials 1, 2; Dickson et al. 2013). Individual layers were reclassified by corresponding scores, then multiplied by the swing weight for that variable. We summed across these reclassified layers and finally rescaled the permeability values for each 300-m cell from 1 through 1000, where 1 and 1000 indicated cells with the lowest and highest permeability, respectively. Use of common ranges of scores and swing weights directly incorporated differences in the ranges of values of different variables and trade-offs among them (Malczewski 2000). For cells that represented barriers, we replaced the calculated permeability values with the expert-defined values for the corresponding barrier types. Detailed methods for these steps are described in Dickson et al. (2013).

\section{Modeling and Mapping Connectivity for Individual Species}

We used circuit-theoretic methods and Circuitscape software (v4.0; circuitscape.org) to estimate connectivity for each species as a function of the permeability layers described above. Circuit models of connectivity represent a given landscape as a network of connected nodes and electrical conductors. The amount of current that passes through a conductor reflects the likelihood of flow (e.g., movement of a species) between its incident nodes. Thus, in addition to a characterization of permeability (i.e., conductance), Circuitscape requires a representation of core areas or nodes-locations at which individuals are most likely to arrive or depart. The locations of cores and areas assumed to direct current (flow of individuals) through particular environmental features are often based on the locations of known populations or discrete patches of habitat assumed to facilitate movement.

Because data on the general locations of known populations or habitat patches within our analysis area were too limited to allow definition of cores for individual species, we calculated and mapped omnidirectional connectivity for each species (Pelletier et al. 2014). We did not produce a point-to-point map of connectivity for particular populations but rather illustrated potential locations throughout the study area through which the species may move. These locations can be evaluated at both regional and local extents. We parameterized each of our connectivity models with the same 2 pairs of cores: the first and last column and the first and last row of each permeability layer. These columns and rows, each of which was one cell wide, reflected the edges of the rectangular study area in the 4 cardinal directions. Given that the models were based on circuit theory, the individual results were undirected; for simplicity, we reference directions as north-south and east-west. For each species, we calculated the cumulative current of these 2 layers to produce a single connectivity surface. With 2 exceptions, our methods were similar to other recent efforts to map connectivity across extensive areas (Pelletier et al. 2014). First, because we did not perceive edge effects in initial analyses across the entire analysis area, we did not divide the analysis area into smaller, identically shaped polygons (tiles) for processing and reassembly (Anderson et al. 2012). Second, we observed that current passing into adjacent areas from a charged core was inversely proportional to the length of that core. To compensate for this effect across a rectangular study area with sides of unequal length, we multiplied each of the 2 current maps by the length of the corresponding core. This calculation normalized the magnitude of current between the individual north-south and east-west output layers from Circuitscape.

\section{Comparing Connectivity Among Species}

To compare connectivity among species, we standardized each single-species connectivity surface (map) by ranking all cells from 1 to 100 on the basis of their percentile values (Breckheimer et al. 2014). We computed the Spearman rank correlation coefficient $(\rho)$ of these values for all pairs of species (Krosby et al. 2015). In addition, we computed and compared the percentage overlap in potential dispersal areas for each species. To identify such areas, we first applied a smoothing function to each connectivity surface, which calculated the mean current within a $10-\mathrm{km}$ radius of each cell. This step removed relatively small areas of high connectivity and better defined relatively large areas. We defined dispersal areas as those with contiguous patches 
TABLE 2. Variable weights [relative strengths of association, $w_{+}(j)$ ], model-averaged regression coefficients $(\widetilde{\bar{\beta}})$, and unconditional standard errors (SE) used to estimate permeability for desert bighorn sheep, American black bear, and pronghorn. Continuous variables were centered to zero and scaled to unit variance. For desert bighorn sheep, ridgelines, canyon bottoms, and steep slopes are discrete classes of topographic position; we used gentle slopes as the reference class. For black bears, the reference land-cover type for forest, woodland, shrubland, and grassland was all other land-cover types inhabited by black bears. For pronghorn, the reference land-cover type for shrubland, grassland, barren, forest, and woodland was all other inhabited land-cover types.

\begin{tabular}{llrrr}
\hline Species & Environmental variable & $w_{+}(j)$ & $\widetilde{\beta}$ & SE \\
\hline Desert bighorn sheep & Slope (degrees) & 1.00 & 0.70 & 0.16 \\
& Vegetation ruggedness measure & 1.00 & 0.49 & 0.10 \\
& Shrub height & 1.00 & 0.39 & 0.23 \\
& Ridgelines & 1.00 & 0.45 & 0.20 \\
& Shrub height * percent cover of shrubland & 1.00 & -0.17 & 0.06 \\
& Percent cover of shrubland & 0.92 & 0.12 & 0.05 \\
& Canyon bottoms & 0.76 & -0.13 & 0.11 \\
& Steep slopes & 0.38 & -0.02 & 0.05 \\
American black bear & Slope (degrees) & 1.00 & 0.72 & 0.20 \\
& Percent cover of vegetation * forest & 0.69 & 0.26 & 0.26 \\
& Percent cover of vegetation * woodland & 0.49 & 0.23 & 0.30 \\
& Percent cover of vegetation & 0.38 & -0.03 & 0.14 \\
& Grassland & 0.33 & -0.10 & 0.21 \\
& Percent cover of vegetation * shrubland & 0.32 & -0.18 & 0.35 \\
& Woodland & 0.31 & -0.06 & 0.17 \\
& Forest & 0.31 & 0.00 & 0.16 \\
& Shrubland & 0.29 & -0.09 & 0.18 \\
& Slope (degrees) & 1.00 & 0.72 & 0.20 \\
& Percent cover of vegetation * forest & 0.69 & 0.26 & 0.26 \\
& Percent cover of vegetation * woodland & 0.49 & 0.23 & 0.30 \\
& Percent cover of vegetation & 0.38 & -0.03 & 0.14 \\
& Grassland & 0.33 & -0.10 & 0.21 \\
& Percent cover of vegetation * shrubland & 0.32 & -0.18 & 0.35 \\
& Woodland & 0.31 & -0.06 & 0.17 \\
& Forest & 0.31 & 0.00 & 0.16 \\
& Shrubland & 0.29 & -0.09 & 0.18 \\
\hline
\end{tabular}

of current in the highest $25 \%$ of values that also were larger than $100 \mathrm{~km}^{2}$. We selected these values to represent what we believed would be a reasonable proportion of the landscape for each species, and patches large enough to support spatially extensive movement. We calculated the percentage overlap for 2 or more species as $100 *$ [(area of overlap * number of species)/sum of the amount of dispersal area for 2 or more species)]. If such areas were independent among species, the expected percentage overlap simply would be the product of the percentage of the study area that was a potential dispersal area for each species.

\section{REsults}

For desert bighorn sheep, the global model of space-use intensity was 1027 AIC units lower than the intercept-only model. Intensity of space use was strongly $([w+(j)] \geq 0.50)$ and positively associated with slope, the vector ruggedness measure, shrub height, ridgelines, and percent cover of shrubland, and negatively associated with canyon bottoms and the interaction between shrub height and the percent cover of shrubland (Table 2). The telemetry data suggested that movement by desert bighorn sheep across hypothesized barriers (state and national highways with 2 or more lanes, large perennial lakes and reservoirs, and the Colorado River) was extremely rare, and we assigned these putative barriers a permeability value of 1 . Connectivity was greatest in areas with steep canyon walls, rugged areas, and shrub-dominated areas. Potential dispersal areas were located east to west along the Grand Canyon and areas northwest of Kayenta, Arizona, and along the Chuska Mountains (Fig. 2). These areas typically had either gentle or steep slopes, and their land cover was dominated by shrubland.

The difference in AIC between the global model and the intercept-only model of spaceuse intensity by black bears was 60 . Space-use 


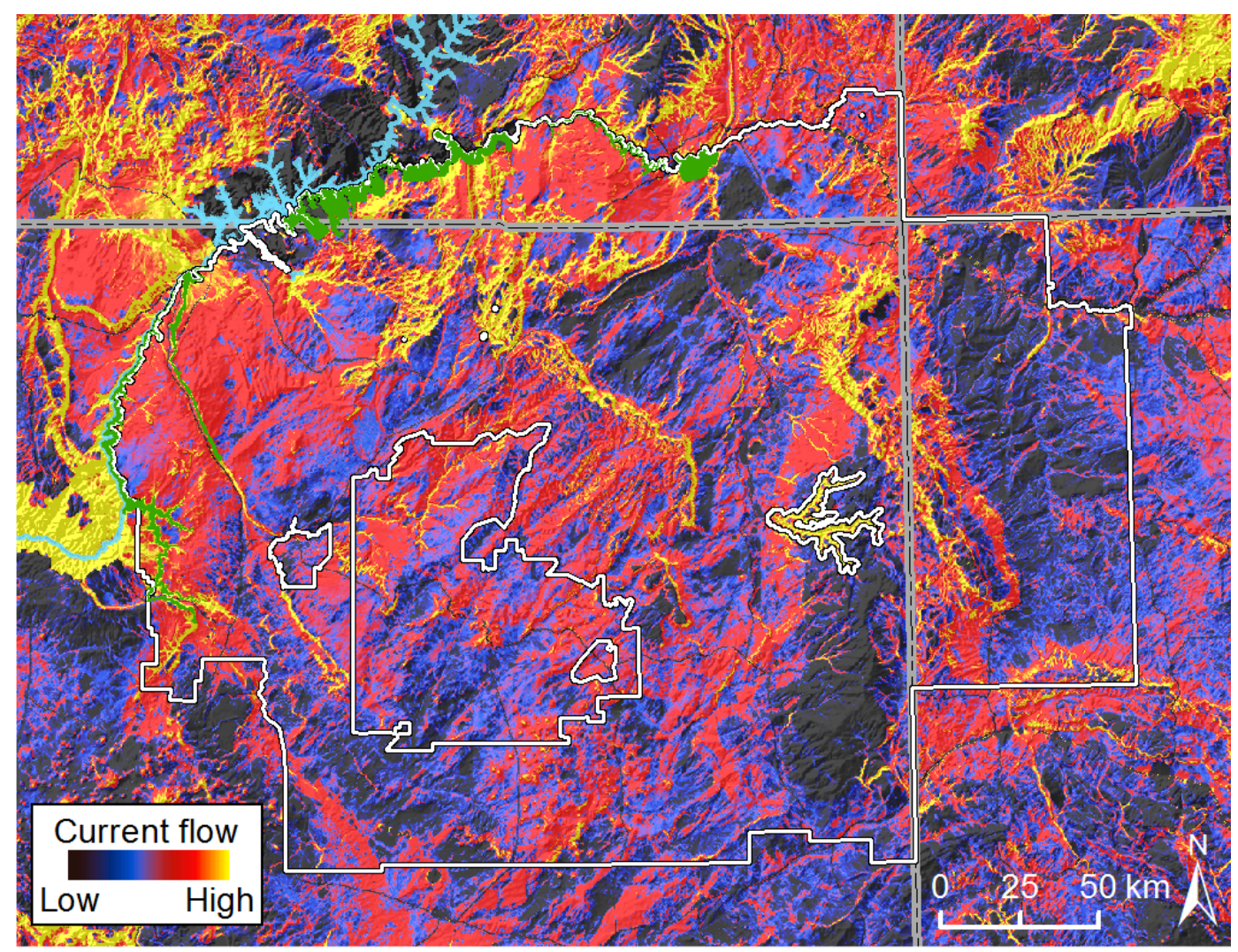

Fig. 2. Connectivity for desert bighorn sheep (Ovis canadensis nelsoni). Black, lowest connectivity; yellow, highest connectivity. The Navajo Nation is outlined in white. The known locations of 4 populations of desert bighorn sheep are outlined in green.

intensity was strongly and positively associated with slope and percent cover of forest (Table 2). Movement did not appear to be impeded by putative barriers; there were 70 crossings of barriers among pairs of the 6900 telemetry locations, and individuals did not appear to avoid barriers. Therefore, we did not include the barriers in the permeability model for this species. The areas of highest connectivity were in canyons, forested montane areas, and dense woodlands. Potential dispersal areas extended across the canyons in the northern portions of the Navajo Nation; across to Black Mesa, southwest of Kayenta, Arizona; and longitudinally across the Chuska Mountains. These areas mostly had gentle or steep slopes (Supplementary Material 3).

For pronghorn, the difference in AIC between the global model and the interceptonly model of space-use intensity was 422 . Six of the 7 variables included in our models were strongly associated with space-use intensity: shrubland, grassland, barren, woodland, forest land cover, and percent cover of forest $>1 \mathrm{~m}$ high (Table 2). Shrubland and grassland were the most strongly and positively associated with space-use intensity. Percent cover of forest $>1 \mathrm{~m}$ high was the most strongly and negatively associated with space-use intensity. Movement of pronghorn across putative barriers was quite restricted. The telemetry data suggested that pronghorn avoided barriers, and there were approximately 15 observed crossings of barriers between any pairs of the nearly 250,000 telemetry locations. Therefore, we assigned these areas a permeability value of 1 . Potential dispersal areas for pronghorn stretched from east to west across the southern portions of the Navajo Nation and from south of Shiprock, New Mexico, to north of Gallup, New Mexico. These areas were dominated by 
TABLE 3. Rank correlation coefficient $(\rho)$ for the geographic distribution of connectivity (upper diagonal) and percentage of overlap between potential dispersal areas (lower diagonal) for pairs of species. If dispersal areas for each species were independent, the expected overlap would be approximately $6.25 \%$.

\begin{tabular}{|c|c|c|c|c|c|}
\hline & $\begin{array}{l}\text { American } \\
\text { black bear }\end{array}$ & $\begin{array}{l}\text { Desert } \\
\text { bighorn sheep }\end{array}$ & Mountain lion & Mule deer & Pronghorn \\
\hline American black bear & & 0.71 & -0.45 & -0.52 & -0.35 \\
\hline Desert bighorn sheep & 73.71 & & -0.36 & -0.40 & 0.04 \\
\hline Mountain lion & 11.77 & 15.84 & & 0.95 & 0.24 \\
\hline Mule deer & 10.89 & 13.15 & 81.93 & & 0.25 \\
\hline Pronghorn & 3.98 & 7.39 & 26.07 & 22.36 & \\
\hline
\end{tabular}

TABLE 4. Percentage of overlap among potential dispersal areas for 3 or more species. Percentages that were greater than expected are in boldface.

\begin{tabular}{lr}
\hline Species & Percentage of overlap \\
\hline Mountain lion, mule deer, pronghorn & $\mathbf{2 0 . 0 1}$ \\
Desert bighorn sheep, mountain lion, mule deer & $\mathbf{1 3 . 0 7}$ \\
American black bear, mountain lion, mule deer & $\mathbf{1 0 . 0 1}$ \\
American black bear, desert bighorn sheep, mountain lion & $\mathbf{8 . 6 2}$ \\
American black bear, desert bighorn sheep, mule deer & $\mathbf{7 . 1 5}$ \\
American black bear, desert bighorn sheep, pronghorn & $\mathbf{3 . 1 6}$ \\
Desert bighorn sheep, mountain lion, pronghorn & 1.07 \\
Desert bighorn sheep, mule deer, pronghorn & 1.05 \\
American black bear, mountain lion, pronghorn & 0.93 \\
American black bear, mule deer, pronghorn & 0.87 \\
American black bear, desert bighorn sheep, mountain lion, mule deer & $\mathbf{7 . 1 0}$ \\
Desert bighorn sheep, mountain lion, mule deer, pronghorn & $\mathbf{1 . 0 5}$ \\
American black bear, mountain lion, mule deer, pronghorn & $\mathbf{0 . 8 7}$ \\
American black bear, desert bighorn sheep, mountain lion, pronghorn & $\mathbf{0 . 4 6}$ \\
American black bear, desert bighorn sheep, mule deer, pronghorn & $\mathbf{0 . 4 6}$ \\
All 5 species & $\mathbf{0 . 4 6}$
\end{tabular}

shrubland, barren land, or grassland and gentle slopes (Supplementary Material 3).

The parameters with the highest swing weights in estimates of permeability for mountain lions were land-cover type and terrain ruggedness (Table 1). Permeability values generally were higher in more highly vegetated land-cover types. Permeability values increased as terrain ruggedness increased, but extremely steep areas (cliffs, defined as the highest 2 deciles of slope) were identified as strong barriers (Supplementary Materials 1, 2). Potential dispersal areas were in the northeastern and southwestern Navajo Nation and southwest of Window Rock, Arizona. These areas typically had gentle slopes, and shrubland was the most common land-cover type (Supplementary Material 3).

Experts on mule deer attributed the highest swing weights to land-cover type, topographic position, and precipitation (Table 1). Woodland, forest, shrubland, and riparian areas typically were assigned higher permeability values than other land-cover classes. Experts also attributed high permeability values to canyon bottoms, gentle slopes, ridgelines, and areas with relatively high mean annual precipitation (Supplementary Material 1, 2). Potential dispersal areas for mule deer, which generally had gentle slopes, were in the southwest portion of the analysis area near Window Rock, Arizona, and Shiprock, New Mexico (Supplementary Material 3).

The rank correlation between the geographic distribution of connectivity for pairs of species ranged from -0.45 to 0.95 and was highest for mountain lions and mule deer (0.95) and for desert bighorn sheep and black bears (0.71; Table 3). If potential dispersal areas for each species were independent, the expected overlap would be approximately $6.3 \%$ for 2 species, $1.5 \%$ for 3 species, $0.4 \%$ for 4 species, and $<0.1 \%$ for 5 species. All but one of the estimated pairwise overlaps in dispersal areas (pronghorn and black bears) were greater than expected (Table 3). Overlap between potential dispersal areas was particularly high for mountain lions and mule deer 


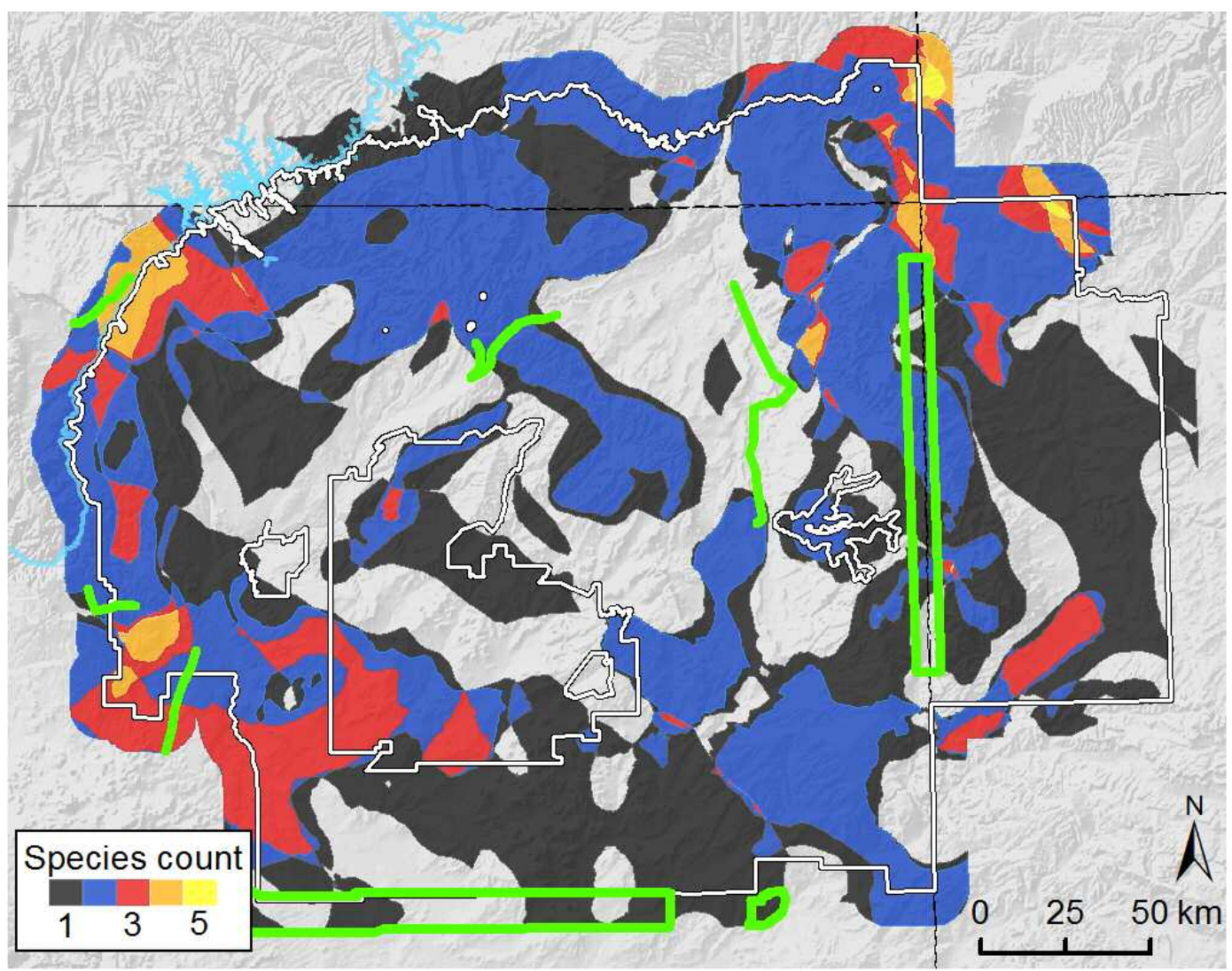

Fig. 3. Overlap in potential dispersal areas for 1 to 5 species. Black, potential dispersal area for 1 species; yellow, potential dispersal area for 5 species. Green lines delineate potential wildlife linkage zones predicted by a separate analysis conducted by the Arizona Department of Transportation.

(82\%) and for black bears and desert bighorn sheep $(74 \%)$. We believe that similarities in associations with slope (terrain) were the major driver of the overlap between black bears and desert bighorn sheep. The percentage of overlap among potential dispersal areas generally decreased as more species were considered, but was greater than expected in 6 of 10 cases for 3 species, and all cases for 4 or 5 species (Table 4). Dispersal areas for 3 or more species were located in the northwestern, southwestern, and northeastern corners of the Navajo Nation (Fig. 3). Dispersal areas for all 5 species overlapped in the northeastern corner and had a total area of approximately $83 \mathrm{~km}^{2}$.

\section{Discussion}

We assessed and compared connectivity and potential dispersal areas for 5 species of large mammals on the Navajo Nation. Different environmental features were associated with estimates of permeability for each species. However, some of these environmental features were similar for pairs or groups of species for which the rank correlation of connectivity and overlap of potential dispersal areas was high. For example, permeability for both mountain lions and mule deer generally was highest in forests and woodlands and lowest in cliff areas, and permeability for both desert bighorn sheep and black bears increased as slope increased. In some instances, connectivity and overlap of potential dispersal areas for species with considerably different diets and other ecological traits (e.g., mountain lions and pronghorn) was high, which may not be expected (Breckheimer et al. 2014). Additionally, for some pairs of species, such as black bears and mountain lions, connectivity was weakly or negatively correlated, 
yet potential dispersal areas overlapped somewhat. Accordingly, some species may share dispersal area due to other factors, such as nearby topographic features that restrict movement (McRae et al. 2008). Overall, although the percentage of overlap of potential dispersal areas was greater than expected in many cases, the area of overlap, especially as the number of species increased, was relatively small.

Our models and the resulting maps represent testable hypotheses about areas in which high-priority species for the Navajo Nation disperse. Although data for the 5 species were limited within the analysis area, we were able to parameterize models of permeability on the basis of empirical data from adjacent areas or expert knowledge. Similarly, we were able to estimate connectivity without distinguishing between core habitat and areas through which the species might move (Dickson et al. 2013). Nevertheless, if additional data were collected within the analysis area, such as telemetry locations for each species, our estimates of connectivity could be evaluated empirically (e.g., LaPoint et al. 2013). Our models also could be refined with additional expert knowledge specific to the Navajo Nation. Results of models for a given species and knowledge of populations of that species in a specific area could be reviewed concurrently to identify areas through which movement of those populations may be likely. As an illustration, we included locations of 4 populations of desert bighorn sheep within the Navajo Nation (Fig. 2 ) in our map of current flow for this species. The latter information on current flow can identify areas to which these populations are most likely to move or expand, or areas in which successful introductions of the species likely would create movement paths to existing populations.

A similar evaluation for 2 or more species could increase the utility of such a review without requiring additional time or cost. For example, we added the locations of potential linkage zones in Arizona and much of the Navajo Nation to our maps of dispersal areas for multiple species (Fig. 3). These zones were identified by a statewide initiative and defined as areas of reduced permeability to wildlife that also may increase habitat connectivity (Eilerts and Nordhaugen 2007). The zones typically were located along highways or in developed areas and suggest areas in which the creation of a linkage (for instance, a wildlife crossing structure across a highway) might increase connectivity. Our results could help suggest where to place such linkages; the zones closest to overlapping potential dispersal areas for the 5 large-mammal species could increase connectivity to a greater extent than other locations.

Although we did not evaluate different methods for assessing connectivity for multiple species, our methods are an alternative to some common approaches, such as extending a species-specific model to other species or using a species-neutral resistance surface (Breckheimer et al. 2014, Krosby et al. 2015). Our use of Circuitscape to estimate omnidirectional connectivity and the methods we applied to define high-connectivity areas allowed for comparison and integration of permeability models derived from different types of data. For example, although we used expert knowledge to estimate permeability for 2 species and models of space-use intensity to estimate permeability for the other 3 species, our maps of current flow and dispersal areas for each species were directly comparable. There is no basis in theory for assuming that estimates and maps derived from these 2 sources of data would differ. Our methods may be most applicable to explicit evaluation of movement for multiple species, or to situations in which correspondence of dispersal areas among species is unknown.

Uncertainty about the extent to which estimates of connectivity are accurate might be reduced by collection of additional field data that are amenable to statistical modeling. In our experience, rigorous statistical models of connectivity for a given species require a minimum of 30 occurrence records from each of a minimum of a dozen individuals that were collected in a systematic and comprehensive manner (Noon et al. 2009). Data might be gathered through camera trapping, telemetry, or other systematic aerial or ground-based surveys. Because spatial extent and resolution may affect the outcome of a model and the associated inferences for resource management, decisions about which methods to apply require one to consider how different species interact with environmental attributes during periods of stasis or movement (Tischendorf and Fahrig 2000).

Extensive vegetation die-offs and biome shifts within the Navajo Nation (Breshears et 
al. 2005, Bogle et al. 2015) have followed decades of drought and increasing mean temperatures (Weiss et al. 2009, Faulstich et al. 2013). Construction of new homes, expansion of utility infrastructure (VanDerslice 2011, Tarasi et al. 2011) and mineral extraction, energy development, and potential increases in the extent of agriculture also may affect connectivity for, and the persistence of, wildlife. Assessment of the trade-offs among diverse land uses and wildlife conservation have informed the Navajo Nation's development of adaptive management scenarios (Nania and Cozetto 2014).

\section{Supplementary Materials}

Three online-only supplementary files accompany this article (scholarsarchive.byu.edu/ wnan/vol77/iss2/11).

Supplementary Material 1. Average, expertdefined permeability values by environmental variable for mountain lion (Puma concolor) (Dickson et al. 2013).

Supplementary Material 2. Average, expertdefined permeability values by environmental variable for mule deer (Odocoileus hemionus).

Supplementary Material 3. Maps of landcover types and single-species connectivity results for American black bear, mountain lion, mule deer and pronghorn.

\section{ACKNOWLEDGMENTS}

Thanks to Jeff Cole and Dexter Prall for guidance on objectives and data availability, Leanna Begay for assistance with data access and outreach, and Tsosie Lewis (Navajo Agricultural Products Industry) for information on potential changes in land use. Our work was supported financially by the U.S. Fish and Wildlife Service via the Southern Rockies Landscape Conservation Cooperative. Thanks to Kevin Johnson and John Rice for their encouragement and advice. We thank the Grand Canyon Research Library and Grand Canyon Association for space and support. Collection of animal locational data was conducted and funded by the Arizona Game and Fish Department with Wildlife Restoration Act funds. We thank K. Bristow, J. Gagnon, L. Harding, J. Heffelfinger, T. McCall, and E. Rubin with the Arizona Game and Fish Department for providing location data or other information on black bears, bighorn sheep, mule deer, and pronghorn. We thank the Wilburforce Foundation and the Grand Canyon Trust for support of the development of the mountain lion and mule deer models.

\section{Literature Cited}

ANDERSOn, D.R. 2007. Model based inference in the life sciences: a primer on evidence. Springer, New York, NY.

Anderson, M.G., M. Clark, and A.O. Sheldon. 2012. Resilient sites for terrestrial conservation in the northeast and mid-Atlantic region. [Accessed 14 June 2016]. http://www.conservationgateway.org/Conser vationByGeography/NorthAmerica/UnitedStates/ edc/Documents/TerrestrialResilience020112.pdf

Atwood, T.C., J.K. Young, J.P. Beckmann, S.W. BREck, J. Fike, O.E. Rhodes, And K.D. BRistow. 2011. Modeling connectivity of black bears in a desert sky island archipelago. Biological Conservation 144: 2851-2862.

Barbieri, M.M., AND J.O. Berger. 2004. Optimal predictive model selection. Annals of Statistics 32:870-897.

Beier, P., W. Spencer, R.F. Baldwin, and B.H. McRae. 2011. Toward best practices for developing regional connectivity maps. Conservation Biology 25:879-892.

Bleich, V.C., J.P. Marshal, and N.G. ANDRew. 2010. Habitat use by a desert ungulate: predicting effects of water availability on mountain sheep. Journal of Arid Environments 74:638-645.

Bogle, R., M.H. Redsteer, and J. Vogel. 2015. Field measurement and analysis of climatic factors affecting dune mobility near Grand Falls on the Navajo Nation, southwestern United States. Geomorphology 228:41-51.

BreckHeimer, I., N.M. HAdDad, W.F. Morris, A.M. Trainor, W.R. Fields, R.T. Jobe, B.R. Hudgens, A. Moody, and J.R. Walters. 2014. Defining and evaluating the umbrella species concept for conserving and restoring landscape connectivity. Conservation Biology 28:1584-1593.

Breshears, D.D., N.S. Cobb, P.M. Rich, K.P. Price, C.D. Allen, R.G. Balice, W.H. Romme, J.H. Kastens, M.L. Floyd, J. Belnap, ET AL. 2005. Regional vegetation die-off in response to global-change-type drought. Proceedings of the National Academy of Sciences 102:15144-15148.

Brodie, J.F., A.J. Giordano, B. Dickson, M. Hebblewhite, H. Bernard, J. Mohd-Azlan, J. Anderson, AND L. AmBu. 2015. Evaluating multispecies landscape connectivity in a threatened tropical mammal community. Conservation Biology 29:122-132.

Brost, B.M., AND P. Beier. 2012. Comparing linkage designs based on land facets to linkage designs based on focal species. PLOS ONE 7:e48965.

Bunn, A.G., D.L. Urban, and T.H. KeItT. 2000. Landscape connectivity: a conservation application of graph theory. Journal of Environmental Management 59:265-278.

Burnham, K.P. 2015. Multimodel inference: understanding AIC relative variable importance values. https://sites.warnercnr.colostate.edu/kenburnham/wpcontent/uploads/sites/25/2016/08/VARIMP.pdf

Burnham, K.P., AND D.R. Anderson. 2002. Model selection and multimodel inference: a practical information-theoretic approach. Springer, New York, NY. 
Carroll, C., B. McRae, and A. Brookes. 2012. Use of linkage mapping and centrality analysis across habitat gradients to conserve connectivity of gray wolf populations in western North America. Conservation Biology 26:78-87.

Chetkiewicz, C.-L.B., C.C. St. Clair, and M.S. Boyce. 2006. Corridors for conservation: integrating pattern and process. Annual Review of Ecology, Evolution, and Systematics 37:317-342.

Correa Ayram, C.A., M.E. Mendoza, A. Etter, and D.R.P. SALICRUP. 2016. Habitat connectivity in biodiversity conservation: a review of recent studies and applications. Progress in Physical Geography 40:7-37.

Cushman, S.A., and E.L. Landguth. 2012. Multi-taxa population connectivity in the northern Rocky Mountains. Ecological Modeling 231:101-112.

DeCesare, N.J., And D.H. Pletscher. 2006. Movements, connectivity, and resource selection of Rocky Mountain bighorn sheep. Journal of Mammalogy 87:531-538.

Dickson, B.G., AND P. BEIER. 2007. Quantifying the influence of topographic position on cougar (Puma concolor) movement in southern California, USA. Journal of Zoology 271:270-277.

Dickson, B.G., G.W. Roemer, B.H. McRae, and J.M. RUNDAL. 2013. Models of regional habitat quality and connectivity for pumas (Puma concolor) in the southwestern United States. PLOS ONE 8:e81898.

Eilerts, B., AND S. Nordhaugen. 2007. Arizona's wildlife linkages assessment. Arizona Department of Transportation; [accessed 16 September 2016]. https://www .azdot.gov/business/environmental-planning/ programs/wildlife-linkages

Epps, C.W., P.J. Palsbøll, J.D. Wehausen, G.K. RoderICK, R.R. Ramey, and D.R. McCullough. 2005. Highways block gene flow and cause a rapid decline in genetic diversity of desert bighorn sheep. Ecology Letters 8:1029-1038.

Faulstich, H.L., C.A. Woodhouse, and D. Griffin. 2013. Reconstructed cool- and warm-season precipitation over the tribal lands of northeastern Arizona. Climatic Change 118:457-468.

Glen, A.S., R.P. PeCH, AND A.E. Byrom. 2013. Connectivity and invasive species management: towards an integrated landscape approach. Biological Invasions $15: 2127-2138$.

Gray, M.E., And B.G. Dickson. 2015. A new model of landscape-scale fire connectivity applied to resource and fire management in the Sonoran Desert, USA. Ecological Applications 25:1099-1113.

Hoglander, C., B.G. Dickson, S.S. Rosenstock, and J.J. ANDERSON. 2015. Landscape models of space use by desert bighorn sheep in the Sonoran Desert of southwestern Arizona. Journal of Wildlife Management 79:77-91.

Horne, J.S., And E.O. Garton. 2006. Likelihood crossvalidation versus least squares cross-validation for choosing the smoothing parameter in kernel homerange analysis. Journal of Wildlife Management 70:641-648.

Kool, J.T., A. Mollanen, and E.A. Treml. 2013. Population connectivity: recent advances and new perspectives. Landscape Ecology 28:165-185.

Krosby, M., I. Breckheimer, D.J. Pierce, P.H. SingleTON, S.A. Hall, K.C. HalupKa, W.L. Gaines, R.A. Long, B.H. McRae, B.L. Cosentino, and J.P. Schuetr-Hames. 2015. Focal species and landscape "naturalness" corridor models offer complementary approaches for connectivity conservation planning. Landscape Ecology 30:2121-2132.

Krosby, M., J. Tewksbury, N.M. Haddad, and J. HoekSTRA. 2010. Ecological connectivity for a changing climate. Conservation Biology 24:1686-1689.

LaPoint, S., P. Gallery, M. Wikelski, and R. Kays. 2013. Animal behavior, cost-based corridor models, and real corridors. Landscape Ecology 28:1615-1630.

Leu, M., S.E. Hanser, C.L. Aldridge, S.E. Nielsen, L.H. SuRING, AND S.T. KNICK. 2011. Occurrence of large and medium-sized mammals: occurrence but not count models predict pronghorn distribution. Pages 315-336 in S.E. Hanser, M. Leu, S.T. Knick, and C.L. Aldridge, editors, Sagebrush ecosystem conservation and management: ecoregional assessment tools and models for the Wyoming Basins. Allen Press, Lawrence, KS.

Loss, S.R., L.A. Terwilliger, and A.C. Peterson. 2011. Assisted colonization: integrating conservation strategies in the face of climate change. Biological Conservation 144:92-100.

Magris, R.A., E.A. Treml, R.L. Pressey, and R. Weeks. 2016. Integrating multiple species connectivity and habitat quality into conservation planning for coral reefs. Ecography 39:649-664.

MalcZewsKi, J. 2000. On the use of weighted linear combination method in GIS: common and best practice approaches. Transactions in GIS 4:5-22.

McRae, B.H., B.G. Dickson, T.H. KeitT, and V.B. Shah. 2008. Using circuit theory to model connectivity in ecology, evolution, and conservation. Ecology 89: 2712-2724.

Merkle, J.A., K.L. Monteith, E.O. Aikens, M.M. Hayes, K.R. Hersey, A.D. Middleton, B.A. Oates, H. Sawyer, B.M. Scurlock, and M.J. Kauffman. 2016. Large herbivores surf waves of green-up during spring. Proceedings of the Royal Society of London B 283:20160456.

Mikesic, D., AND D. Roth. 2008. Navajo Nation endangered species list species accounts. Navajo Natural Heritage Program, Window Rock, AZ; [accessed 14 June 2016]. http://www.nnfdw.org/nnhp/nnhp_nesl .pdf

Mollohan, C.M. 1987. Characteristics of adult female black bear daybeds in northern Arizona. International Conference on Bear Research and Management 7:145-149.

Nania, J., AND K. CozetTo. 2014. Considerations for climate change and variability adaptation on the Navajo Nation. University of Colorado, Boulder, CO.

Noon, B.R., K.S. McKelvey, and B.G. Dickson. 2009. Multispecies conservation planning on US federal lands. Pages 51-83 in J.J. Millspaugh and F.R. Thompson III, editors, Models for planning wildlife conservation in large landscapes. Elsevier, London.

NoyCE, K.V., AND D.L. GARShELIS. 2011. Seasonal migrations of black bears (Ursus americanus): causes and consequences. Behavioral Ecology and Sociobiology 65:823-835.

Pelletier, D., M. Clark, M.G. Anderson, B. Rayfield, M.A. Wulder, AND J.A. CARDILLE. 2014. Applying circuit theory for corridor expansion and management at regional scales: tiling, pinch points, and omnidirectional connectivity. PLOS ONE 9:e84135.

Poor, E.E., C. Loucks, A. Jakes, And D.L. Urban. 2012. Comparing habitat suitability and connectivity 
modeling methods for conserving pronghorn migrations. PLOS ONE 7:e49390.

Santini, L., S. Saura, and C. Rondinini. 2016. A composite network approach for assessing multi-species connectivity: an application to road defragmentation prioritisation. PLOS ONE 11:e0164794.

Sappington, J.M., K.M. Longshore, and D.B. ThompSON. 2007. Quantifying landscape ruggedness for animal habitat analysis: a case study using bighorn sheep in the Mojave desert. Journal of Wildlife Management 71:1419-1426.

Silverman, B.W. 1986. Density estimation for statistics and data analysis. Chapman and Hall, London.

Singleton, P.H., W.L. Gaines, And J.F. Lehmkuhl. 2002. Landscape permeability for large carnivores in Washington: a Geographic Information System weighted-distance and least-cost corridor assessment. U.S. Department of Agriculture, Forest Service, Pacific Northwest Research Station, Portland, OR; [accessed 14 June 2016]. http://www.fs.fed .us/pnw/pubs/rp549

Spear, S.F., N. Balkenhol, M.-J. Fortin, B.H. McRae, AND K. SCRIBNER. 2010. Use of resistance surfaces for landscape genetic studies: considerations for parameterization and analysis. Molecular Ecology 19:3576-3591.

Tarasi, D., C. Alexander, J. Nania, and B. Gregor. 2011. 18,000 Americans without electricity: illuminating and solving the Navajo energy crisis. Colorado Journal of International Environmental Law and Policy 22:263-447.

Theobald, D.M., S.E. Reed, K. Fields, and M. Soulé. 2012. Connecting natural landscapes using a landscape permeability model to prioritize conservation activities in the United States. Conservation Letters $5: 123-133$.

Tischendorf, L., and L. Fahrig. 2000. How should we measure landscape connectivity? Landscape Ecology 15:633-641.

VanDerslice, J. 2011. Drinking water infrastructure and environmental disparities: evidence and methodological considerations. American Journal of Public Health 101:S109-S114.

Weiss, J.L., C.L. Castro, and J.T. Overpeck. 2009. Distinguishing pronounced droughts in the southwestern United States: seasonality and effects of warmer temperatures. Jounal of Climatology 22:5918-5932.

Willems, E.P., AND R.A. Hill. 2009. Predator-specific landscapes of fear and resource distribution: effects on spatial range use. Ecology 90:546-555.

WILLIAMS, R.L. 2000. A note on robust variance estimation for cluster-correlated data. Biometrics 56:645-646.

Worton, B.J. 1989. Kernel methods for estimating the utilization distribution in home-range studies. Ecology 70:164-168.

Zeller, K.A., K. MCGarigal, and A.R. Whiteley. 2012. Estimating landscape resistance to movement: a review. Landscape Ecology 27:777-797.

Zuur, A.F., E.N. IEno, N.J. Walker, A.A. Saveliev, and G.M. Sмiтh. 2009. Mixed effects models and extensions in ecology with R. Springer, New York, NY.

Received 31 October 2016 Accepted 23 March 2017 Published online 20 July 2017 